\title{
Effects of simulated quarter and udder teat cup removal settings on strip milk and milking duration in dairy cows
}

\author{
P. Silva Boloña, ${ }^{1,2 *}$ (ㄷ J. Upton, ${ }^{2}$ () and D. J. Reinemann ${ }^{3}$ \\ ${ }^{1}$ Department of Dairy Science, University of Wisconsin-Madison, 53706 \\ ${ }^{2}$ Animal and Grassland Research and Innovation Centre, Teagasc Moorepark Fermoy, Co. Cork, P61 C996, Ireland \\ ${ }^{3}$ Biological Systems Engineering Department, University of Wisconsin-Madison, 53706
}

\begin{abstract}
The aim of this study was to estimate the amount of milk left in quarters and udders and the milking duration for a variety of teat cup removal strategies. A combination of empirical data and simulated quarter and udder teat cup removal settings were used to make these estimates. Milking duration is an important factor in both automatic and conventional milking systems because it directly influences milking efficiency and hence can affect farm profitability. Strategies investigated in the literature to reduce milking duration include the application of different milk flow rate switch-points (milk flow rate at which the milking unit or teat cup is removed). Applying these milk flow rate switch-points can affect the amount of milk that is not harvested (strip milk). We are not aware of previous research analyzing strip milk yield and milking duration at the quarter level, across a range of quarter and udder milk flow rate switch-points. Quarter-level average milking duration decreased by 2 min, and strip milk increased $1.3 \mathrm{~kg}$ as quarter milk flow rate switch-point was increased from $0.2 \mathrm{~kg} / \mathrm{min}$ to $1.0 \mathrm{~kg} / \mathrm{min}$. Using an end of milking criterion of removal of the teat cup at $50 \%$ of the quarter's rolling average milk flow rate resulted in a 0.4 -min reduction in milking duration and a 0.08 $\mathrm{kg}$ increase in strip milk per quarter, compared with removal of the teat cup at 30\% of the quarter's rolling average milk flow rate. Udder-level average milking duration decreased by $1.4 \mathrm{~min}$, and strip milk increased by $0.76 \mathrm{~kg}$ ( $0.19 \mathrm{~kg}$ per quarter) as udder milk flow rate switch-point was increased from $0.2 \mathrm{~kg} / \mathrm{min}$ to $1.0 \mathrm{~kg} /$ min. A 0.8 -min reduction in cow milking duration and a $0.27-\mathrm{kg}$ increase in strip milk at the udder level $(0.08$ $\mathrm{kg}$ per quarter) resulted when changing udder milk flow rate switch-point from $30 \%$ of the udder rolling average to $50 \%$ of the udder rolling average milk flow rate. This
\end{abstract}

Received July 15, 2019.

Accepted December 29, 2019

*Corresponding author: psilva2@wisc.edu study provides quantitative estimates of the effect of teat cup milk flow rate switch-points on milking duration and strip milk yield.

Key words: teat cup removal setting, strip milk, milking duration, milking efficiency

\section{INTRODUCTION}

The increase seen in milk yield per cow over the past decades has contributed to increased milking duration; however, longer milkings do not always result in greater milk yield. The duration of milking is an important consideration in dairy farming for both conventional and automatic milking systems (AMS). In conventional milking systems, the need to minimize production costs and the difficulties of finding skilled labor make the milking process a challenging activity (Jago et al., 2010), especially because milking is the most labor-intensive task on dairy farms, accounting for 33\% of overall labor demand (Deming et al., 2018). In AMS, key factors driving efficiency and productivity are milking duration and total time spent milking per day in the robot (Gygax et al., 2007). Morveover, Castro et al. (2012) found that one of the most important factors determining milk yield per AMS and per year was average milk flow rate, which was inversely associated with milking duration.

The desire for shorter milkings has driven research on teat cup removal settings. At the udder level, Edwards et al. (2013) saw a reduction in milking duration of $18 \%$ when the cluster milk flow rate switch-point (milk flow rate at which the cluster is removed) increased from $0.2 \mathrm{~kg} / \mathrm{min}$ to $0.8 \mathrm{~kg} / \mathrm{min}$ at the udder level. Also, Burke and Jago (2011) found that milking duration was reduced by $11 \%$ by increasing the cluster milk flow rate switch-point from $0.2 \mathrm{~kg} / \mathrm{min}$ to $0.4 \mathrm{~kg} / \mathrm{min}$ at the udder level. In high-producing dairy cows, Stewart et al. (2002) found a 10- to 15-s reduction in milking duration by increasing the milk flow rate switch-point from $0.73 \mathrm{~kg} / \mathrm{min}$ to $0.82 \mathrm{~kg} / \mathrm{min}$ at the udder level. At the quarter level, Ipema and Hogewerf (2002) found a $10 \%$ reduction in milking duration when quarter milk 
flow rate switch-point was increased from 0.05 to 0.15 $\mathrm{kg} / \mathrm{min}$, and Krawczel et al. (2017) found that milking duration was $0.9 \mathrm{~min}(12 \%)$ shorter when the teat cup milk flow rate switch-point was increased from $0.06 \mathrm{~kg} /$ min to $0.48 \mathrm{~kg} / \mathrm{min}$ at the quarter level.

Increasing the milk flow rate switch-point can result in variable amounts of unharvested milk, which could result in a reduction in milk production and negative effects on udder health and milk quality, although the degree of undermilking at which these effects might occur is not well known. The influence of milk remaining in the gland on reducing milk secretion is thought to be due to the accumulation of substances that modulate milk secretion when in contact with epithelial cells (Henderson and Peaker, 1987; Weaver and Hernandez, 2016). The influence and causal effect of milk remaining in the gland on SCC is less clear. A study by Penry et al. (2017) found a slight increase in SCC from 26,300 to 48,300 cells $/ \mathrm{mL}$ and a $25 \%$ reduction in milk production rate when approximately $30 \%$ of the milk was left in a half udder when cows were milked twice per day. A subsequent study by Kuehnl et al. (2019) showed that regardless of whether half udders were milked 2 or 3 times per day, they had $27 \%$ lower milk production and SCC increased by 25,700 cells $/ \mathrm{mL}$ compared with half udders milked completely. However, Rasmussen (1993) found no differences in clinical or subclinical mastitis when comparing a cluster switch-point of 0.2 $\mathrm{kg} / \mathrm{min}$ with $0.4 \mathrm{~kg} / \mathrm{min}$ applied at the udder level. Moreover, Burke and Jago (2011) found that changing cluster milk flow rate switch-point from $0.2 \mathrm{~kg} / \mathrm{min}$ to $0.4 \mathrm{~kg} / \mathrm{min}$ at the udder level did not negatively affect SCC; however, a small (1\%) but statistically significant drop in milk yield was observed. Additionally, Clarke et al. (2008) reported that removing the clusters at 0.8 $\mathrm{kg} / \mathrm{min}$, compared with $0.3 \mathrm{~kg} / \mathrm{min}$ at the udder level, did not cause an increase in SCC for either infected or uninfected quarters. In an AMS, Krawczel et al. (2017) saw no effect on SCC or milk yield when teat cup milk flow rate switch-point was increased from $0.06 \mathrm{~kg} / \mathrm{min}$ to $0.48 \mathrm{~kg} / \mathrm{min}$ at the quarter level. The study by Penry et al. (2017) measured the milk left in the quarter, and thus it is not comparable with a specific milk flow rate switch-point used in other studies. As a reference, the studies by Edwards et al. (2013) and Clarke et al. (2008) reported increases in strip milk of approximately $0.3 \mathrm{~L}$ at the udder level when increasing the milk flow rate switch-point up to $0.8 \mathrm{~kg} / \mathrm{min}$. It seems clear that the effect of undermilking on milk yield and the potential effect on SCC is volume-dependent and that the relationship between milk left in the gland and its effect on milk production and milk quality is not entirely understood.
It is important to understand how milk left in the quarter and milking duration are affected when different milk flow rate switch-points at the quarter and udder level are used. Our hypothesis was that increasing the milk flow rate switch-point would reduce milking duration and increase strip milk. Therefore, the objective of this study was to quantify the effects of different simulated teat cup milk flow rate switch-points applied at the quarter and udder level on milking duration and the amount of milk left in the quarters and udders.

\section{MATERIALS AND METHODS}

\section{Cow Selection}

We used 17 Holstein Friesian cows from the Dairy Cattle Center herd from the University of WisconsinMadison. Cows were housed in individual tiestalls with bedded mattresses and were fed a TMR diet. These animals were part of an 84 milking-cow herd, averaging approximately $40 \mathrm{~kg} / \mathrm{cow}$ per day, that were milked twice a day (at 0400 and $1600 \mathrm{~h}$ ) at the udder level in a herringbone parlor. Cows used in this study were selected to have a wide range of lactations (mean 2.5, SD 1.7, range 1 to 7 ) and DIM (mean 240, SD 100, range 99 to 418). The average udder milk yield per milking for the experimental cows was $14 \mathrm{~kg}$ (SD 3.1, range 9.8 to 19 ) with an average quarter milk yield of $3.6 \mathrm{~kg}$ (SD 0.9 , range 1.6 to 5.9 ).

\section{Milking}

Seven cows were milked once on one day, and a power study was done with these data to estimate the number of cows and quarters needed to achieve a detectable difference of less than $1 \%$ in quarter-level milk yield and milking duration. Based on these calculations a second group of 10 cows were milked once on a subsequent day.

Cows were completely milked using a novel quarter milking device (Mi4, Upton et al., 2016), using a vacuum level of $43 \mathrm{kPa}, 65: 35$ pulsator ratio, and pulsation rate of 60 cycles per minute. The experimental cows were milked before the afternoon milking with a resulting milking interval that ranged from 8 to 11 h. Cumulative quarter-level milk weights were recorded throughout the milking at a frequency of 1,000 HZ. The milking routine consisted of pre-stripping for detection of clinical mastitis, followed by pre-dipping and cleaning of the quarters before attachment of the teat cups. Machine stripping was applied when observation of the milking unit indicated that no milk was being extracted, to ensure that all milk was removed from each quarter. The total amount of milk extracted during the 
milking (including machine stripping) was taken as the total milk yield at the quarter or udder level.

\section{Data Management}

Milk flow rates $(\mathrm{kg} / \mathrm{min})$ were determined by linear regression of milk weight versus time in 5-s increments. Peak milk flow rate $(\mathbf{P M F}, \mathrm{kg} / \mathrm{min})$ was calculated as the maximum 30-s rolling average milk flow rate (an average of six 5-s milk flow rate measurements).

Algorithms were developed in SAS (v. 9.4, fourth ed., SAS Institute Inc., Cary, NC) to determine the milking duration (MD, min) from teat cup attachment to simulated teat cup removal and amount of milk harvested up to the simulated teat cup removal for different removal strategies. Strip milk weight (SM, $\mathrm{kg}$ ) was calculated as the total milk yield (including machine stripping) minus the milk harvested up to the point of simulated teat cup removal. Additionally, the slowest-milking quarter within an udder was identified for each milk flow rate switch-point and MD was calculated. For the udder-level analysis, information from the 4 quarters of a cow was aggregated, and quarter SM, udder SM, and cow MD were calculated. Average milk flow rate (AMF, $\mathrm{kg} / \mathrm{min})$ was calculated as kilograms of milk harvested from teat cup attachment to simulated teat cup removal, divided by the simulated milking duration.

Five removal strategies used the 5-s-interval absolute milk flow rate as the switch-point criterion for teat cup removal at the quarter and udder level: $0.2 \mathrm{~kg} /$ min (MFR0.2), $0.4 \mathrm{~kg} / \mathrm{min}$ (MFR0.4), $0.6 \mathrm{~kg} / \mathrm{min}$ (MFR0.6), $0.8 \mathrm{~kg} / \mathrm{min}$ (MFR0.8), and $1.0 \mathrm{~kg} / \mathrm{min}$ (MFR1.0). Two strategies used a percentage of the 30 -s rolling average milk flow rate as the criterion for teat cup removal at the quarter and udder level: $30 \%$ (RAMF30) or $50 \%$ (RAMF50). The subscripts $\mathrm{Q}$ and ${ }_{\mathbf{U}}$ are used to identify whether the treatment or response is measured at quarter or udder level (e.g., $\mathbf{M D}_{\mathrm{Q}}$ and $\mathbf{M D}_{\mathrm{U}}$ for quarter and udder milking duration, respectively).

One quarter registered a milk flow rate of zero during the majority of the milking and was removed from the quarter analysis because the milk flow rate switch-point was not applicable for such a low flow rate. For the quarter-level percentage-based switch-points, 3 quarters never reached the milk flow rate switch-point for either removal level and were removed from the quarter analysis for the RAMF $30_{\mathrm{Q}}$ and RAMF $50_{\mathrm{Q}}$ treatments. One cow did not reach the udder-level percentage-based milk flow rate switch-point and was removed from the udder analysis for the RAMF30 $0_{\mathrm{U}}$ and RAMF50 $0_{\mathrm{U}}$ treatments.

\section{Statistical Analysis}

We used a mixed model procedure (Proc Mixed, SAS 9.4). Model selection was conducted by offering all possible explanatory variables to the model using a backward selection method, and the final model was selected based on the lowest Akaike information criterion value. Treatment (MFR0.2, MFR0.4, MFR0.6, MFR0.8, and MFR1.0, or RAMF30 and RAMF50) and cow were declared as class variables. We classified SM, MD, PMF, and milk yield as continuous variables. Treatment and PMF were classified as fixed effects. Cow was declared as a random variable. A repeated measures statement was included in the model to address the repeated data from quarters within cow. Additionally, to account for repeated measures at the quarter level, a compound symmetry error structure was used. The effects of the day a cow was milked, lactation number, and DIM were not significant.

The final model for MD for the slowest quarter and for SM and MD for the quarter and whole udder was

$$
y=\text { Treatment }+ \text { MilkYield }+P M F,
$$

where $y$ represented the following dependent variables: $\mathrm{SM}_{\mathrm{Q}}, \mathrm{SM}_{\mathrm{U}}$ [strip milk weight $\left.(\mathrm{kg})\right]$, the weight of milk left after teat cup or cluster removal at the quarter and udder levels, respectively; $\mathrm{MD}_{\mathrm{Q}}, \mathbf{M D}_{\mathrm{SQ}}$, and $\mathrm{MD}_{\mathrm{U}}$ [milking duration (min)], time from cluster or teat cup attachment to cluster or teat cup detachment at the quarter, slowest quarter, and udder levels, respectively.

For treatments applied at the udder level, the outcomes and covariates were all taken as udder-level statistics. Descriptive statistics were also calculated at the quarter level for these udder-level treatements. Quarters were ranked according to their within-udder milking duration, with the fastest quarter having the shortest milking duration and the slowest quarter the longest milking duration. Overmilking duration of each quarter was determined by the elapsed time from when that quarter had a milk flow rate less than $0.2 \mathrm{~kg} / \mathrm{min}$ to when the udder reached the switch-point (Figure 1). The SM was also calculated at the quarter level for these within-udder rankings (Figure 2).

\section{RESULTS}

\section{Milking Duration}

Absolute Milk Flow Rate Switch-Point. For treatments applied at the quarter level, $\mathrm{MD}_{Q}$ decreased by $2.0 \mathrm{~min}$ as the switch-point increased from MFR0.2 $2_{\mathrm{Q}}$ to MFR1.0 $(P<0.001$; Table 1$)$. Milk yield 
was strongly associated with $\operatorname{MD}_{\mathrm{Q}}(P<0.0001)$ with each kilogram increase in milk yield increasing $\mathrm{MD}_{\mathrm{Q}}$ by $0.7 \mathrm{~min}$ (data not shown). We also found a negative association between $\mathrm{MD}_{\mathrm{O}}$ and quarter-level PMF $(P<0.0001)$ with each $1.0 \mathrm{~kg} / \mathrm{min}$ increase in PMF, resulting in a 1.1-min reduction in $\mathrm{MD}_{\mathrm{O}}$. The slowest quarter had a 2.2 -min decrease in $\mathrm{MD}_{\mathrm{SQ}}(P<0.001)$ as the switch-point increased (Table 1).

Treatments applied at the udder level resulted in $\mathrm{MD}_{\mathrm{U}}$ decreasing by $1.4 \mathrm{~min}(P<0.001)$ as the switchpoint increased from MFR0.2 $2_{\mathrm{U}}$ to MFR1.0 $0_{\mathrm{U}}$ (Table 2). Descriptive statistics for quarter-level overmilking time (defined as quarter milk flow rate $<0.2 \mathrm{~kg} / \mathrm{min}$ ) are shown in Figure 1. Both udder milk yield and PMF were highly associated with $\mathrm{MD}_{\mathrm{U}}(P<0.0001)$, with each $1.0-\mathrm{kg}$ increase in milk yield and PMF resulting in 0.3-min longer and 0.8-min shorter $\mathrm{MD}_{\mathrm{U}}$ respectively.

Percentage-Based Switch-Point. For the quarter-level treatments, $\mathrm{MD}_{\mathrm{Q}}$ was 0.4 min shorter $(P<$ 0.001) for RAMF $50_{\mathrm{Q}}$ than for RAMF $30_{\mathrm{Q}}$ (Table 1). For the slowest quarter, $\mathrm{MD}_{\mathrm{SQ}}$ was 0.5 min shorter $(P=$ $0.0006)$ for RAMF $50_{Q}$ than for RAMF $30_{Q}$ (Table 1). The estimated teat cup removal milk flow rate for the RAMF $50_{\mathrm{Q}}$ setting was $0.17 \mathrm{~kg} / \mathrm{min}$ and $0.06 \mathrm{~kg} / \mathrm{min}$ for the RAMF $30_{\mathrm{Q}}$ setting at the quarter level.
For udder-level treatments, $\mathrm{MD}_{\mathrm{U}}$ was 0.8 min shorter $(P=0.01)$ for RAMF50 $0_{\mathrm{U}}$ than for RAMF $30_{\mathrm{U}}$. The absolute milk flow rate at simulated cluster removal averaged $0.14 \mathrm{~kg} / \mathrm{min}$ for the RAMF30 $0_{\mathrm{U}}$ treatment and 0.45 $\mathrm{kg} / \mathrm{min}$ for the RAMF50 5 treatment. Quarter overmilking times, with udder milk flow rate switch-points, are shown in Figure 1.

\section{Strip Milk}

Absolute Milk Flow Rate Switch-Point. For quarter-level treatments $\mathrm{SM}_{\mathrm{Q}}$ increased by $1.3 \mathrm{~kg}(P<$ 0.001 ) from MFR0. $2_{\mathrm{Q}}$ to MFR1. $0_{\mathrm{Q}}$ (Table 1). Both quarter PMF and milk yield were associated $(P<0.0001)$ with $\mathrm{SM}_{\mathrm{Q}}$, decreasing by $1.0 \mathrm{~kg}$ for each kilogram-perminute increase in quarter PMF and increasing by 0.3 $\mathrm{kg}$ per kilogram increase in milk yield. Treatments applied at the udder level also resulted in an increase of $0.76 \mathrm{~kg}$ in $\mathrm{SM}_{\mathrm{U}}(P<0.001)$ from MFR0.2 $2_{\mathrm{U}}$ to MFR1.0 (Table 2). Descriptive statistics for SM at the quarter level with the udder level milk flow rate switch-points are presented in Figure 2.

Percentage-Based Switch-Point. For quarter-level treatments, $\mathrm{SM}_{\mathrm{Q}}$ was $0.08 \mathrm{~kg}$ greater for RAMF50 than for RAMF30 $(P=0.02)$ (Table 1$)$, whereas for

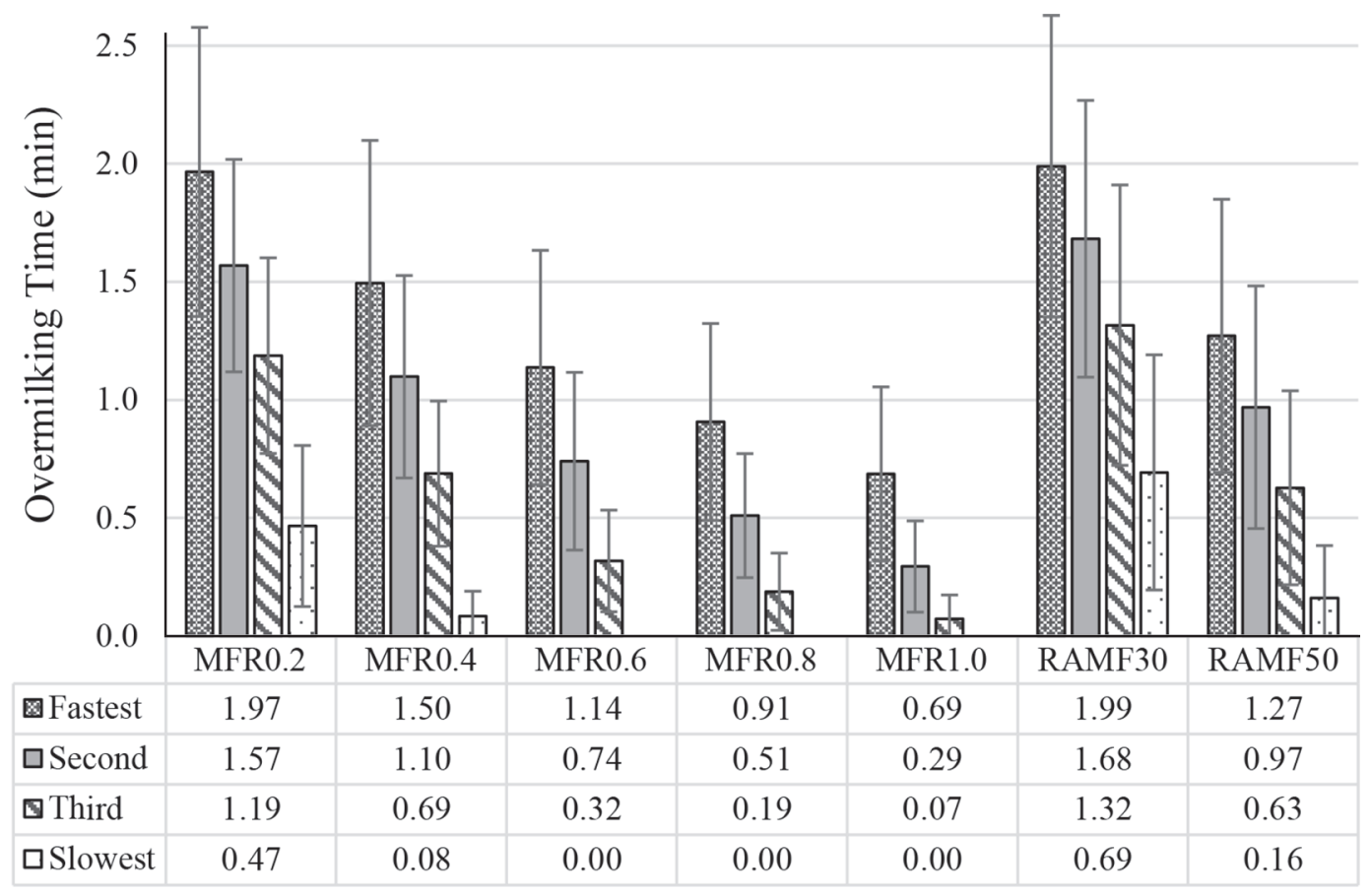

Figure 1. Quarter overmilking duration with udder milk flow rate switch-points ranked according to within-udder milking duration. Fastest $=$ quarter with the shortest milking duration in the udder; second $=$ quarter with the second-shortest milking duration in the udder; third $=$ quarter with the third-shortest milking duration in the udder; slowest $=$ quarter with the longest milking duration in the udder. MFR0.2 $=$ simulated cluster milk flow switch-point at $0.2 \mathrm{~kg} / \mathrm{min} ; \mathrm{MFR} 0.4=$ simulated cluster milk flow switch-point at $0.4 \mathrm{~kg} / \mathrm{min} ; \mathrm{MFR} 0.6=$ simulated cluster milk flow switch-point at $0.6 \mathrm{~kg} / \mathrm{min} ; \mathrm{MFR} 0.8=$ simulated cluster milk flow switch-point at $0.8 \mathrm{~kg} / \mathrm{min}$; MFR $1.0=$ simulated cluster milk flow switch-point at $1.0 \mathrm{~kg} / \mathrm{min} ; \mathrm{RAMF} 30=$ simulated cluster milk flow switch-point at $30 \%$ of the average flow rate; RAMF50 = simulated cluster milk flow switch-point at $50 \%$ of the average flow rate. Error bars represent SD. 


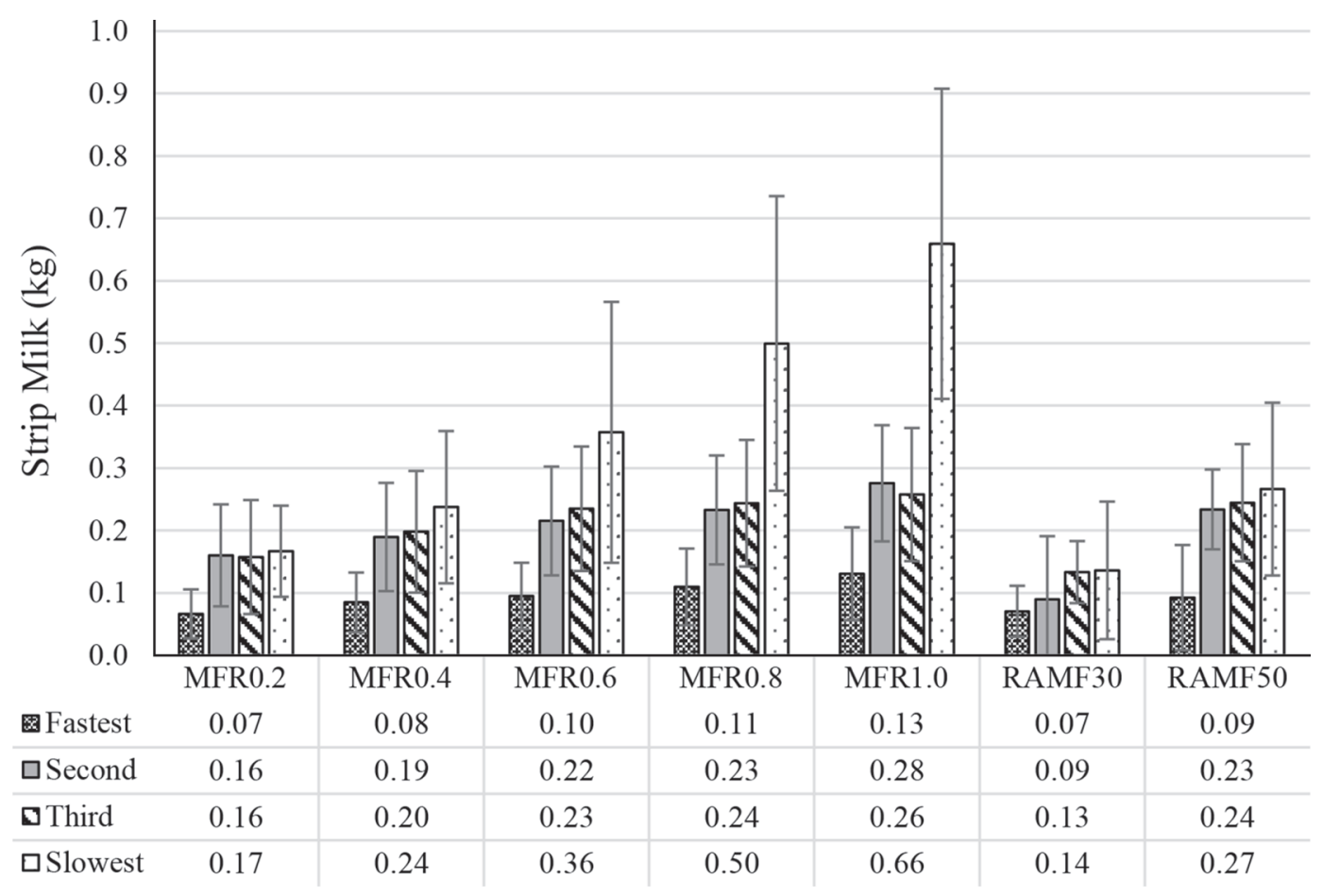

Figure 2. Quarter strip milk with udder milk flow rate switch-points ranked according to within-udder milking duration. Fastest $=$ quarter with the shortest milking duration in the udder; second $=$ quarter with the second-shortest milking duration in the udder; third $=$ quarter with the third-shortest milking duration in the udder; slowest $=$ quarter with the longest milking duration in the udder. MFR0.2 = simulated cluster milk flow switch-point at $0.2 \mathrm{~kg} / \mathrm{min}$; MFR0.4 = simulated cluster milk flow switch-point at $0.4 \mathrm{~kg} / \mathrm{min}$; MFR0.6 = simulated cluster milk flow switch-point at $0.6 \mathrm{~kg} / \mathrm{min}$; MFR0.8 = simulated cluster milk flow switch-point at $0.8 \mathrm{~kg} / \mathrm{min}$; MFR1.0 = simulated cluster milk flow switchpoint at $1.0 \mathrm{~kg} / \mathrm{min}$; RAMF30 = simulated cluster milk flow switch-point at 30\% of the average flow rate; RAMF50 = simulated cluster milk flow switch-point at $50 \%$ of the average flow rate. Error bars represent SD.

treatments applied at the udder level, $\mathrm{SM}_{\mathrm{Q}}$ was 0.07 $\mathrm{kg}$ and $\mathrm{SM}_{\mathrm{U}}$ was $0.27 \mathrm{~kg}$ greater for RAMF50 than for RAMF30 $\left(P<0.001\right.$ and $P=0.02$ for $\mathrm{SM}_{\mathrm{Q}}$ and $\mathrm{SM}_{\mathrm{U}}$, respectively; Table 2). Neither $\mathrm{SM}_{\mathrm{Q}}$ nor $\mathrm{SM}_{\mathrm{U}}$ were associated with milk yield or PMF for the percentagebased treatments at the quarter or udder level.
At the quarter level, we found weak evidence $(P=$ $0.04)$ that AMF was affected by the treatment, with only the MFR $0.2_{\mathrm{Q}}$ having a lower AMF than the other treatments. The percentage reduction in $\mathrm{MD}$ and milk yield were similar, resulting in little change in AMF. At the udder level a significant increase in $\operatorname{AMF}(P<$

Table 1. Results of teat cup removal strategies applied at the quarter level

\begin{tabular}{|c|c|c|c|c|c|c|c|c|c|c|c|}
\hline \multirow[b]{2}{*}{ Item } & \multicolumn{11}{|c|}{ Simulated treatment ${ }^{1}$} \\
\hline & $\operatorname{MFR} 0.2_{\mathrm{Q}}$ & $\operatorname{MFR} 0.4_{\mathrm{Q}}$ & $\operatorname{MFR} 0.6_{\mathrm{Q}}$ & $\operatorname{MFR} 0.8_{\mathrm{Q}}$ & $\operatorname{MFR} 1.0_{\mathrm{Q}}$ & SEM & $P$-value & $\mathrm{RAMF} 30_{\mathrm{Q}}$ & RAMF $50_{\mathrm{Q}}$ & SEM & $P$-value \\
\hline $\begin{array}{l}\text { Quarter strip milk } \\
{[\mathrm{kg}(\%)]}\end{array}$ & $\begin{array}{c}0.2^{\mathrm{a}} \\
(7.3)\end{array}$ & $\begin{array}{r}0.4^{\mathrm{a}} \\
(13.0)\end{array}$ & $\begin{array}{r}0.8^{\mathrm{b}} \\
(23.6)\end{array}$ & $\begin{array}{r}1.2^{\mathrm{c}} \\
(34.1)\end{array}$ & $\begin{array}{r}1.5^{\mathrm{d}} \\
(42.3)\end{array}$ & 0.08 & $<0.001$ & $\begin{array}{l}0.20^{\mathrm{a}} \\
(5.6)\end{array}$ & $\begin{array}{l}0.28^{\mathrm{b}} \\
(8.1)\end{array}$ & 0.04 & 0.02 \\
\hline $\begin{array}{l}\text { Quarter milking } \\
\text { duration (min) }\end{array}$ & $4.4^{\mathrm{a}}$ & $4.0^{\mathrm{b}}$ & $3.3^{\mathrm{c}}$ & $2.7^{\mathrm{d}}$ & $2.4^{\mathrm{e}}$ & 0.11 & $<0.001$ & $4.7^{\mathrm{a}}$ & $4.3^{\mathrm{b}}$ & 0.12 & $<0.001$ \\
\hline $\begin{array}{l}\text { Slowest quarter milking } \\
\text { duration (min) }\end{array}$ & $5.2^{\mathrm{a}}$ & $4.8^{\mathrm{ab}}$ & $4.4^{\mathrm{b}}$ & $3.3^{\mathrm{c}}$ & $3.0^{\mathrm{c}}$ & 0.22 & $<0.001$ & $5.8^{\mathrm{a}}$ & $5.3^{\mathrm{b}}$ & 0.22 & $<0.001$ \\
\hline
\end{tabular}

\footnotetext{
${ }^{\mathrm{a}-\mathrm{e}}$ Different letters within a parameter indicate significant differences between the treatments at the $\alpha=0.05$ level.

${ }^{1} \mathrm{LSM}$ for the simulated treatments. MFR $0.2_{\mathrm{Q}}=$ simulated teat cup milk flow switch-point at $0.2 \mathrm{~kg} / \mathrm{min} ;$ MFR $0.4_{\mathrm{Q}}=$ simulated teat cup milk flow switch-point at $0.4 \mathrm{~kg} / \mathrm{min} ;$ MFR $0.6_{\mathrm{Q}}=$ simulated teat cup milk flow switch-point at $0.6 \mathrm{~kg} / \mathrm{min} ; \mathrm{MFR} 0.8_{\mathrm{Q}}=$ simulated teat cup milk flow switch-point at $0.8 \mathrm{~kg} / \mathrm{min} ; \mathrm{MFR} 1.0_{\mathrm{Q}}=$ simulated teat cup milk flow switch-point at $1.0 \mathrm{~kg} / \mathrm{min} ;$ RAMF $30_{\mathrm{Q}}=$ simulated teat cup milk flow switch-point at $30 \%$ of the average flow rate; RAMF $50_{Q}=$ simulated teat cup milk flow switch-point at $50 \%$ of the average flow rate. Values in parentheses represent strip milk as a percentage the total milk available for harvesting.
} 
0.05) occurred as milk flow rate switch-point increased (data not shown).

\section{DISCUSSION}

As the simulated milk flow rate switch-point was increased at both the quarter and udder level, we saw a steady decrease in MD and a steady increase in $\mathrm{SM}$ at the quarter and udder levels. There are clear advantages to reducing MD to improve the labor and capital efficiency of milk harvesting. These are balanced against the potential negative effects of increased SM: primarily reduced milk production and, secondarily, changes in milk components and other aspects of milk quality. This study was undertaken to gain a better understanding of the effects of teat cup removal strategies on both MD and SM.

The 1.1-min $(19 \%)$ reduction in $\mathrm{MD}_{\mathrm{U}}$ between our MFR $0.2_{\mathrm{U}}$ and MFR $0.8_{\mathrm{U}}$ treatments was comparable to the 1.3-min (18\%) reduction found by Edwards et al. (2013). The $\mathrm{MD}_{\mathrm{U}}$ reduction of $0.5 \mathrm{~min}(9 \%)$ between our MFR0. $2_{\mathrm{U}}$ and MFR0.4 $4_{\mathrm{U}}$ treatments was also consistent with Jago et al. (2010), who reported a 0.7-min (11\%) reduction in $\mathrm{MD}_{\mathrm{U}}$ in mid- to late-lactation cows with the same milk flow rate switch-point increase, a smaller reduction compared with early-lactation cows. Edwards et al. (2014) reported a shorter decline phase in mid- to late-lactation, which helps explain this smaller effect. Besier and Bruckmaier (2016) reported that simulated MD was reduced by $1.3 \mathrm{~min}$ (or 19\%) for a constant vacuum treatment when the udder-level milk flow rate switch-point was increased from $0.2 \mathrm{~kg} / \mathrm{min}$ to $1.0 \mathrm{~kg} /$ min. This reduction compares well with our result of a 1.4-min reduction in $\mathrm{MD}_{\mathrm{U}}$ but with a somewhat greater percentage reduction (25\%). Our average milk yield per milking was slightly less (14 kg vs. $15.4 \mathrm{~kg}$ ) and our AMF and PMF were higher $(2.5 \mathrm{~kg} / \mathrm{min}$ vs. $1.89 \mathrm{~kg} /$ min for AMF, and 4.2 vs. $3.27 \mathrm{~kg} / \mathrm{min}$ for PMF), resulting in shorter milking duration (5.7 min vs. $6.7 \mathrm{~min}$ for the MFR0.2 $2_{\mathrm{U}}$ treatment) than the study by Besier and Bruckmaier (2016), explaining our larger percentage reduction in MD.

When milk flow rate switch-points were applied at the quarter level, our predicted reduction in $\mathrm{MD}_{\mathrm{Q}}(2.0 \mathrm{~min}$ from MFR $0.2_{\mathrm{Q}}$ to MFR $1.0_{\mathrm{Q}}$ ) was considerably larger than the reduction in $\mathrm{MD}_{\mathrm{U}}$ for the same switch-point applied at the udder level (1.4 min from MFR0.2 $2_{\mathrm{Q}}$ to MFR1.0 $0_{Q}$ ). A study by Krawczel et al. (2017) reported a $0.9-\min (12 \%)$ reduction in MD between $0.06 \mathrm{~kg} /$ min and $0.48 \mathrm{~kg} / \mathrm{min}$ switch-point settings. Although the switch-point settings used in our study were not the same as those used by Krawczel et al. (2017), the reduction in MD was comparable: 0.4-min (9\%) reduction in $\mathrm{MD}_{\mathrm{Q}}$ between MFR0.2 $2_{\mathrm{Q}}$ and MFR0.4 $4_{\mathrm{Q}}$, and 1.1min $(25 \%)$ reduction between MFR0. $2_{\mathrm{Q}}$ and MFR $0.6_{\mathrm{Q}}$.

For treatments applied at the udder level, considerable within-udder differences in overmilking duration occurred for individual quarters (Figure 1). Overmilking is an undesirable condition because it leads to unnecessary extension of the milking and can lead to deterioration of teat end condition (Hillerton et al., 2002). A study by Sandrucci et al. (2007) reported an udder overmilking duration of $0.8 \mathrm{~min}$, corresponding to $12.8 \%$ of the milking time. Our study showed a large variation between the quarters within an udder. The average overmilking duration for the fastest quarter of each udder was reduced by 1.28 min across the udderlevel MFR treatments, whereas average overmilking duration of the slowest milking quarter of each udder was reduced by $0.47 \mathrm{~min}$ (Figure 1 ). This indicates that when the udder reaches the milk flow rate switch-point, most of the milk has been removed in several quarters, which also explains the differences in SM with the switch-points applied at the quarter and udder levels. Moreover, when we analyzed the MD of the slowest milking quarter, we found that $\mathrm{MD}_{\mathrm{SQ}}$ approached $\mathrm{MD}_{\mathrm{Q}}$ for the highest switch-points applied at the quarter level and approached $\mathrm{MD}_{\mathrm{U}}$ for the lowest switch-points

Table 2. Results of teat cup removal strategies applied at the udder level

\begin{tabular}{|c|c|c|c|c|c|c|c|c|c|c|c|}
\hline \multirow[b]{2}{*}{ Item } & \multicolumn{11}{|c|}{ Simulated treatment ${ }^{1}$} \\
\hline & $\operatorname{MFR} 0.2_{\mathrm{U}}$ & $\operatorname{MFR} 0.4_{U}$ & MFR0.6 $6_{U}$ & MFR $0.8_{U}$ & MFR1.0 $0_{U}$ & SEM & $P$-value & ${\text { RAMF } 30_{U}}$ & RAMF $50_{U}$ & SEM & $P$-value \\
\hline $\begin{array}{l}\text { Udder strip milk, } \\
{[\mathrm{kg}(\%)]}\end{array}$ & $\begin{array}{l}0.54^{\mathrm{a}} \\
(3.8)\end{array}$ & $\begin{array}{l}0.70^{\mathrm{a}} \\
(5.0)\end{array}$ & $\begin{array}{l}0.89^{\mathrm{b}} \\
(6.4)\end{array}$ & $\begin{array}{l}1.07^{\mathrm{b}} \\
(7.6)^{2}\end{array}$ & $\begin{array}{l}1.30^{\mathrm{c}} \\
(9.4)\end{array}$ & 0.12 & $<0.001$ & $\begin{array}{l}0.55^{\mathrm{a}} \\
(4.0)\end{array}$ & $\begin{array}{l}0.82^{\mathrm{b}} \\
(6.0)\end{array}$ & 0.11 & 0.02 \\
\hline $\begin{array}{l}\text { Udder milking } \\
\text { duration (min) }\end{array}$ & $5.7^{\mathrm{a}}$ & $5.2^{b}$ & $4.8^{\mathrm{c}}$ & $4.6^{\mathrm{cd}}$ & $4.3^{\mathrm{d}}$ & 0.19 & $<0.001$ & $5.7^{\mathrm{a}}$ & $4.9^{\mathrm{b}}$ & 0.29 & 0.01 \\
\hline
\end{tabular}

\footnotetext{
${ }^{\mathrm{a}-\mathrm{d}}$ Different letters within a parameter indicate significant differences between the treatments at the $\alpha=0.05$ level.

${ }^{1} \mathrm{LSM}$ for the simulated treatments. MFR $0.2_{\mathrm{U}}=$ simulated cluster milk flow switch-point at $0.2 \mathrm{~kg} / \mathrm{min} ;$ MFR0.4 $4_{\mathrm{U}}=$ simulated cluster milk flow switch-point at $0.4 \mathrm{~kg} / \mathrm{min} ;$ MFR0. $6_{\mathbf{U}}=$ simulated cluster milk flow switch-point at $0.6 \mathrm{~kg} / \mathrm{min} ; \mathrm{MFR} 0.8_{\mathrm{U}}=$ simulated cluster milk flow switchpoint at $0.8 \mathrm{~kg} / \mathrm{min} ; \mathrm{MFR} 1.0_{\mathrm{U}}=$ simulated cluster milk flow switch-point at $1.0 \mathrm{~kg} / \mathrm{min} ; \mathrm{RAMF} 30_{\mathrm{U}}=$ simulated cluster milk flow switch-point at $30 \%$ of the average flow rate; RAMF $50_{U}=$ simulated cluster milk flow switch-point at $50 \%$ of the average flow rate. Values in parentheses represent strip milk as a percentage the total milk available for harvesting.
} 
applied at the udder level. This finding, combined with the overmilking results, where the 3 fastest quarters are being overmilked for a substantial period of time for switch-points below $0.6 \mathrm{~kg} / \mathrm{min}$, suggest that the slowest quarter is the main determinant of $\mathrm{MD}_{\mathrm{U}}$ when those switch-points are used. Additionally, considering the excessive time some quarters are being milked with a very low milk flow, or with no milk flow, further strategies for optimal quarter milkability while achieving minimal overmilking could be explored for conventional milking systems.

Our results for strip milk were also in general agreement with other studies. Jago et al. (2010) and Edwards et al. (2013) found no difference in $\mathrm{SM}_{\mathrm{U}}$ between the MFR0. $2_{\mathrm{U}}$ and the MFR0. $4_{\mathrm{U}}$ treatments, in agreement with our result. Burke and Jago (2011) did, however, report a small difference in $\mathrm{SM}_{\mathrm{U}}$ between MFR0.2 $2_{\mathrm{U}}$ and the MFR $0.4_{\mathrm{U}}$ treatments $(0.19 \mathrm{~kg}$ vs. $0.35 \mathrm{~kg}$, respectively, which represented $1.9 \%$ and $3.4 \%$ of the total milk yield). Besier and Bruckmaier (2016) estimated that a simulated $1.0 \mathrm{~kg} / \mathrm{min}$ switch-point applied at the udder level resulted in SM of $6.9 \%$ of the total milk yield. Given their udder level milk yield of $15.8 \mathrm{~kg}$, this would result in a SM of about $1.1 \mathrm{~kg}$, which was close to our result of $1.3 \mathrm{~kg}$ or $9.4 \%$ of total udder milk yield for our MFR1. $0_{\mathrm{U}}$ treatment.

Analysis revealed differences of up to $1.3 \mathrm{~kg}$ in $\mathrm{SM}_{\mathrm{Q}}$ between treatments applied at the quarter level in this study. We are not aware of literature reporting the effect of switch-point on SM at the quarter level. Additionally, we found considerably more $\mathrm{SM}_{\mathrm{Q}}$ for treatments applied at the quarter level ( $42 \%$ of the quarter milk yield) than $\mathrm{SM}_{\mathrm{Q}}$ for treatments applied at the udder level (9.4\% of the quarter milk yield), and this increased as the milk flow rate switch-point was increased. For MFR0.2 ${ }_{\mathrm{Q}}$, the estimate for $\mathrm{SM}_{\mathrm{Q}}$ was 0.2 $\mathrm{kg}$, whereas for MFR0.2 $2_{\mathrm{U}}$ the $\mathrm{SM}_{\mathrm{Q}}$ ranged from 0.07 $\mathrm{kg}$ to $0.17 \mathrm{~kg}$. When the switch-point was increased to $1 \mathrm{~kg} / \mathrm{min}$, the MFR1. $0_{\mathrm{Q}}$ treatment resulted in $\mathrm{SM}_{\mathrm{Q}}$ of $1.5 \mathrm{~kg}$, and MFR1. $0_{\mathrm{U}}$ resulted in a range of $\mathrm{SM}_{\mathrm{Q}}$ from $0.13 \mathrm{~kg}$ to $0.66 \mathrm{~kg}$. This is due to the differences in milk flow rate characteristics at the udder and quarter levels. Weiss et al. (2004) reported that the end of the plateau phase in a quarter was related to the milk available in that quarter, whereas the end of the plateau phase at the udder level was determined by the duration of this phase in the fastest milking quarter. Tančin et al. (2007) also reported that at the udder level, the decline phase begins when the first quarter begins its decline phase and continues in a stepwise order until the slowest milking quarter completes this phase, resulting in different degrees of emptiness of the quarters when the udder-level switch-point is used. This pattern is also apparent in the average quarter-level overmilk- ing durations (Figure 1). For the MFR0.2 $2_{U}$ treatment the fastest milking quarter had an overmilking time of almost 2 min and steps down by increments of about $0.5 \mathrm{~min}$ for the second-fastest, third-fastest, and slowest quarters occurred as a result of the sequential emptying of quarters.

We found large within-udder variability in $\mathrm{SM}_{\mathrm{Q}}$ that increased as the udder-level switch-point was increased (Figure 2). For the lowest switch-point (MFR2.0 $0_{\mathrm{U}}$ ), we discovered little difference in SM between quarters, but at the highest switch-point (MFR1.0 $0_{\mathrm{U}}$ ), the average SM of the slowest quarter was about 5 times greater than that of the fastest milking quarter.

To our knowledge, no previous studies have simulated a percentage-based milk flow rate switch-point at the udder or quarter level and their effect on MD or quarter SM. This switch-point strategy is used at the quarter level by some AMS. Our analysis also included application of this strategy at the udder level. In our study, the reduction in $\mathrm{MD}_{\mathrm{U}}$ was similar to the 0.7-min difference, or a $12 \%$ reduction, between the $0.2 \mathrm{~kg} /$ min and $0.4 \mathrm{~kg} / \mathrm{min}$ removal settings reported in the Edwards et al. (2013) study. The estimated absolute milk flow rate at teat cup removal for the RAMF $50_{\mathrm{Q}}$ switch-point was $0.17 \mathrm{~kg} / \mathrm{min}$ and $0.06 \mathrm{~kg} / \mathrm{min}$ for the RAMF $30_{\mathrm{Q}}$ switch-point at the quarter level, and were lower than the flow rates deployed in any of the absolute flow rate switch-points studied, which may explain the lower reduction of MD between the treatments. In our study the percentage-based milk flow rate switchpoint resulted in SM and MD similar to the lowest absolute flow rate switch-point strategies. Use of a 30-s rolling average comparison for determination of the switch-point results in less reduction of MD for cows or quarters that have a prolonged decline phase.

Although this study was not designed to test the effect of SM on milk production, our results can help in the interpretation of previous studies and in the design of new studies to explore this relationship. Krawczel et al. (2017) found no differences in daily milk yield between $0.06,0.3$, and $0.48 \mathrm{~kg} / \mathrm{min}$ switch-points applied at the quarter level but did not measure SM. Our study suggests that the $\mathrm{SM}_{\mathrm{Q}}$ for these treatments would have been on the order of $0.1 \mathrm{~kg}, 0.3 \mathrm{~kg}$, and $0.6 \mathrm{~kg}$, respectively. Penry et al. (2017) and Kuehnl et al. (2019) reported significantly lower milk production rates when early-lactation cows were severely undermilked, leaving about $1.4 \mathrm{~kg}$ of $\mathrm{SM}$ in a quarter. Our study suggests that MFR1.0 $0_{\mathrm{Q}}$ would produce a similar $\mathrm{SM}_{\mathrm{Q}}$. Burke and Jago (2011) reported a 1\% lower milk yield for a $0.4 \mathrm{~kg} / \mathrm{min}$ udder-level switch-point than for a $0.2 \mathrm{~kg} / \mathrm{min}$ udder-level switch-point in a long-term study. They attributed this difference to the proportion of cows having a strip yield higher than $0.5 \mathrm{~L}$ at 
the udder level. The slowest milking quarters for our MRF0.2 $2_{\mathrm{U}}$ treatment averaged $0.17 \mathrm{~kg} \mathrm{SM}_{\mathrm{Q}}$, and the slowest milking quarters for our MFR0.4 $4_{U}$ treatment averaged $0.24 \mathrm{~kg} \mathrm{SM} \mathrm{S}_{\mathrm{Q}}$. Edwards et al. (2013) found no differences in milk yield between a $0.2 \mathrm{~kg} / \mathrm{min}$ and a 0.8 $\mathrm{kg} / \mathrm{min}$ switch-point even though significant differences in $\mathrm{SM}_{\mathrm{U}}$ occurred between the 2 treatments $(0.27 \mathrm{~kg}$ vs. $0.57 \mathrm{~kg}$ ), which is in contradiction to the Burke and Jago (2011) study and not explained by our results. For the MFR0. $8_{\mathrm{U}}$ switch-point Edwards et al. (2013) reported lower $\mathrm{SM}_{\mathrm{U}}(0.57 \mathrm{~kg}$ vs. $1.1 \mathrm{~kg})$ and higher MD (6.0 min vs. $4.6 \mathrm{~min}$ ) than our study for similar milk yield per milking (14.9 kg vs. $14 \mathrm{~kg}$ ). The differences in MD and SM may be due to differences in the milk flow rate characteristics of cows or to differences in the way that the $0.8 \mathrm{~kg} / \mathrm{min}$ switch-point criteria was calculated and applied by the commercial milk meter used in the Edwards et al. (2013) study.

We found that PMF was negativley associated with both $\mathrm{SM}_{\mathrm{Q}}$ and $\mathrm{SM}_{\mathrm{U}}$ for MFR treatements, but PMF was not associated with $\mathrm{SM}_{\mathrm{Q}}$ or $\mathrm{SM}_{U}$ for the percentage-based milk flow rate switch-points. These results are partially in contrast with Weiss et al. (2004), who did not find a correlation between PMF and SM at either quarter or udder level, although they did find a negative correlation between SM and the duration of the plateau phase at the quarter level and negative correlation between the durations of the plateau and decline phases at the quarter level but not at the udder level. Our calculation of PMF was the maximum 30-s rolling average milk flow rate, whereas the PMF used by Weiss et al. (2004) was averaged over the entire plateau phase of milking, which could be several minutes in duration. Our calculation method likely resulted in higher PMF values than did the method used by Weiss et al. (2004). We also did not take into account any effects related to the duration of the decline phase or the shape of the milk flow curve, which were shown by Weiss et al. (2004) to influence SM.

\section{CONCLUSIONS}

Increasing the simulated milk flow rate switch-point from $0.2 \mathrm{~kg} / \mathrm{min}$ to $1.0 \mathrm{~kg} / \mathrm{min}$ at the quarter level reduced $\mathrm{MD}_{\mathrm{Q}}$ by $2.0 \mathrm{~min}(45 \%)$ and, at the udder level, reduced $\mathrm{MD}_{\mathrm{U}}$ by $1.4 \mathrm{~min}(25 \%)$. The same treatments resulted in an increase in $\mathrm{SM}_{\mathrm{Q}}$ from $0.2 \mathrm{~kg}$ to $1.5 \mathrm{~kg}$ and an increase in $\mathrm{SM}_{\mathrm{U}}$ from $0.56 \mathrm{~kg}$ to $1.3 \mathrm{~kg}$. Increasing the simulated percentage-based switch-point from $30 \%$ of the rolling average milk flow rate to $50 \%$ of the rolling average flow rate at the quarter level reduced $\mathrm{MD}_{\mathrm{Q}}$ by $0.4 \mathrm{~min}(9 \%)$ and, at the udder level, reduced $\mathrm{MD}_{\mathrm{U}}$ by $0.8 \mathrm{~min}(14 \%)$. With the same increase in percentage-based switch-points, $\mathrm{SM}_{\mathrm{Q}}$ increased from
$0.20 \mathrm{~kg}$ to $0.28 \mathrm{~kg}$, and $\mathrm{SM}_{\mathrm{U}}$ increased from 0.56 to 0.84 $\mathrm{kg}$. Teat cup removal settings applied at the udder level produced considerably more within-udder variation in overmilking and $\mathrm{SM}_{\mathrm{Q}}$ than did application at the quarter level. The results of this study can be used to aid in interpretation of previous studies on teat cup removal strategies in which $\mathrm{MD}_{\mathrm{Q}}, \mathrm{SM}_{\mathrm{Q}}$, or $\mathrm{SM}_{\mathrm{U}}$ were not measured and to aid in the design of new experiments to gain better understanding of how teat cup removal settings affect SM, milk yield, and milk quality.

\section{ACKNOWLEDGMENTS}

The authors gratefully acknowledge the financial support of the Teagasc Walsh Fellowships Programme (Teagasc Oak Park, Carlow, Ireland) and the University of Wisconsin-Madison. We acknowledge the technical assistance of Scott Sanford and the staff at the Dairy Cattle Center of the University of Wisconsin-Madison in the operation of the experiment. We acknowledge Peter Crump at the Statistical Consulting Group in the College of Agricultural and Life Sciences (CALS), University of Wisconsin-Madison, for statistical advice. The authors have not stated any conflicts of interest.

\section{REFERENCES}

Besier, J., and R. M. Bruckmaier. 2016. Vacuum levels and milk-flowdependent vacuum drops affect machine milking performance and teat condition in dairy cows. J. Dairy Sci. 99:3096-3102. https:// doi.org/10.3168/jds.2015-10340.

Burke, J. K., and J. G. Jago. 2011. Comparing somatic cell counts, production and milking durations of dairy cows when milked at two automatic cup-removal flow-rate thresholds. Anim. Prod. Sci. 51:920-924. https://doi.org/10.1071/AN11042.

Castro, A., J. M. Pereira, C. Amiama, and J. Bueno. 2012. Estimating efficiency in automatic milking systems. J. Dairy Sci. 95:929-936. https://doi.org/10.3168/jds.2010-3912.

Clarke, T., E. M. Cuthbertson, R. K. Greenall, M. C. Hannah, and D. Shoesmith. 2008. Incomplete milking has no detectable effect on somatic cell count but increased cell count appears to increase strip yield. Aust. J. Exp. Agric. 48:1161-1167. https://doi.org/10 $.1071 /$ EA07259.

Deming, J., D. Gleeson, T. O'Dwyer, J. Kinsella, and B. O'Brien. 2018. Measuring labor input on pasture-based dairy farms using a smartphone. J. Dairy Sci. 101:9527-9543. https://doi.org/10 $.3168 /$ jds.2017-14288.

Edwards, J. P., J. G. Jago, and N. Lopez-Villalobos. 2014. Analysis of milking characteristics in New Zealand dairy cows. J. Dairy Sci. 97:259-269. https://doi.org/10.3168/jds.2013-7051.

Edwards, J. P., J. G. Jago, and N. Lopez-Villalobos. 2013. Milking efficiency for grazing dairy cows can be improved by increasing automatic cluster remover thresholds without applying premilking stimulation. J. Dairy Sci. 96:3766-3773. https://doi.org/10.3168/ jds.2012-6394.

Gygax, L., I. Neuffer, C. Kaufmann, R. Hauser, and B. Wechsler. 2007. Comparison of functional aspects in two automatic milking systems and auto-tandem milking parlors. J. Dairy Sci. 90:4265-4274. https://doi.org/10.3168/jds.2007-0126.

Henderson, A. J., and M. Peaker. 1987. Effects of removing milk from the mammary ducts and alveoli, or of diluting stored milk, on the rate of milk secretion in the goat. Q. J. Exp. Physiol. 72:13-19. https://doi.org/10.1113/expphysiol.1987.sp003039. 
Hillerton, J. E., J. W. Pankey, and P. Pankey. 2002. Effect of overmilking on teat condition. J. Dairy Res. 69:81-84. https://doi.org/10 $.1017 /$ S0022029901005386.

Ipema, B., and P. Hogewerf. 2002. Detachment criteria and milking duration. Pages 33-34 in Proc. 1st North Am. Conf., Robotic Milking, Toronto, Canada. Wageningen Academic Publishers, Wageningen, The Netherlands.

Jago, J. G., J. L. Burke, and J. H. Williamson. 2010. Effect of automatic cluster remover settings on production, udder health, and milking duration. J. Dairy Sci. 93:2541-2549. https://doi.org/10 $.3168 /$ jds.2009-2949.

Krawczel, P., S. Ferneborg, L. Wiking, T. K. Dalsgaard, S. Gregersen, R. Black, T. Larsen, S. Agenäs, K. Svennersten-Sjaunja, and E. Ternman. 2017. Milking time and risk of over-milking can be decreased with early teat cup removal based on udder quarter milk flow without loss in milk yield. J. Dairy Sci. 100:6640-6647. https: //doi.org/10.3168/jds.2016-12312.

Kuehnl, J. M., M. K. Connelly, A. Dzidic, M. Lauber, H. P. Fricker, M. Klister, E. Olstad, M. Balbach, E. Timlin, V. Pszczolkowski, P. M. Crump, D. J. Reinemann, and L. L. Hernandez. 2019. The effects of incomplete milking and increased milking frequency on milk production rate and milk composition. J. Anim. Sci. 97:2424-2432. https://doi.org/10.1093/jas/skz113.

Penry, J. F., E. L. Endres, B. de Bruijn, A. Kleinhans, P. M. Crump, D. J. Reinemann, and L. L. Hernandez. 2017. Effect of incomplete milking on milk production rate and composition with 2 daily milkings. J. Dairy Sci. 100:1535-1540. https://doi.org/10.3168/jds .2016-11935.

Rasmussen, M. D. 1993. Influence of switch level of automatic cluster removers on milking performance and udder health. J. Dairy Res. 60:287-297. https://doi.org/10.1017/S0022029900027631.
Sandrucci, A., A. Tamburini, L. Bava, and M. Zucali. 2007. Factors affecting milk flow traits in dairy cows: Results of a field study. J. Dairy Sci. 90:1159-1167. https://doi.org/10.3168/jds.S0022 -0302(07)71602-8.

Stewart, S., S. Godden, P. Rapnicki, D. Reid, A. Johnson, and S. Eicker. 2002. Effects of automatic cluster remover settings on average milking duration, milk flow, and milk yield. J. Dairy Sci. 85:818-823. https://doi.org/10.3168/jds.S0022-0302(02)74141-6.

Tančin, V., A. H. Ipema, and P. Hogewerf. 2007. Interaction of somatic cell count and quarter milk flow patterns. J. Dairy Sci. 90:22232228. https://doi.org/10.3168/jds.2006-666.

Upton, J., D. J. Reinemann, J. F. Penry, and P. D. Thompson. 2016. A quarter milking analysis device-Development and demonstration. Biosyst. Eng. 147:259-264. https://doi.org/10.1016/j .biosystemseng.2016.04.016.

Weaver, S. R., and L. L. Hernandez. 2016. Autocrine-paracrine regulation of the mammary gland. J. Dairy Sci. 99:842-853. https://do .org/10.3168/jds.2015-9828.

Weiss, D., M. Weinfurtner, and R. M. Bruckmaier. 2004. Teat anatomy and its relationship with quarter and udder milk flow characteristics in dairy cows. J. Dairy Sci. 87:3280-3289. https://doi.org/ 10.3168/jds.S0022-0302(04)73464-5.

\section{ORCIDS}

P. Silva Boloña ๑ https://orcid.org/0000-0002-5866-6943

J. Upton (1) https://orcid.org/0000-0002-6142-8372 